\title{
Pencegahan Penyakit Scabies di Lembaga Pemasyarakatan Perempuan Kelas II B Yogyakarta
}

\author{
Ubaidillah $^{1}$ \\ ${ }^{1}$ Prodi Kesehatan Masyarakat, Stikes Surya Global Yogyakarta \\ *Email koresponden: bd_ubaidillah@yahoo.com
}

\section{ARTICLE INFO}

Article history

Received: 22 Ags 2020

Accepted: 25 Mar 2021

Published: 23 Apr 2021

\section{Kata kunci:}

Rumah Tahanan

Sarcoptes scabiei Scabies

\section{Keyword:}

Detention House

Sarcoptes scabiei Scabies

\begin{abstract}
A B S T R A K
Background: Scabies adalah infeksi kulit yang disebabkan oleh tungau Sarcoptes scabiei berukuran kecil yang hidup di dalam kulit penderita. Ciri khas dari scabies adalah gatal-gatal hebat, yang biasanya semakin memburak pada malam hari Kondisi penjara yang kurang memadai tentunya menjadi faktor risiko timbulnya berbagai penyakit menular salah satunya adalah skabies. Tujuan dari acara pengabdian masyarakat ini adalah untuk memberikan edukasi yang tepat kepada penghuni Rutan tentang penyakit scabies serta untuk memberikan edukasi kepada penghuni Rutan tentang Sanitasi lingkungan dan Higiene perseorangan sebagai faktor penghambat terjadinya penularan scabies. Metode: Metode yang dilakukan adalah dengan memberikan pendidikan dan penyuluhan dengan menggunakan slide projector serta memberikan pertanyaan untuk menilai tingkat kepahaman audiens. Hasil: Hasil yang didapatkan ketika diberikan pertanyaan, para audiens rata-rata menjawab dengan benar yang menandakan para audiens sudah mengerti akan arti pentingnya tentang Sanitasi lingkungan dan Higiene perseorangan. Kesimpulan: Terdapat peningkatan pengetahuan tentang scabies dan higiene dan sanitasi perseorangan.
\end{abstract}

\begin{abstract}
A B S T R A C T
Background: Scabies is a skin infection caused by Sarcoptes scabiei mite that lives in a small patient's skin. A characteristic feature of scabies is severe itching, which usually worsens at night. Inadequate prison conditions will certainly be a risk factor for various infectious diseases, one of which is scabies. The purpose of this community service program is to provide appropriate education to residents of detention centers about scabies and to provide education to residents of detention centers on environmental sanitation and personal hygiene as inhibiting factors for scabies transmission. Methods: The method used is to provide education and counseling using a slide projector and provide questions to assess the level of understanding of the audience Results: The results obtained when asked questions, the average audience answers correctly which indicates the audience has understood the importance of environmental sanitation and personal hygiene. Conclusions: There is an increase in knowledge about scabies and personal hygiene and sanitation.
\end{abstract}

\section{PENDAHULUAN}

Skabies merupakan penyakit kulit yang endemis di wilayah beriklim tropis dan subtropis seperti Afrika, Amerika selatan, Karibia, Australia tengah dan selatan, dan Asia. Prevalensi skabies pada anak berusia 6 tahun di Bangladesh adalah 23-29\% dan di Kamboja 43\%. Studi di rumah kesejahteraan di Malaysia tahun 2010 menunjukkan prevalensi 30\% dan di Timor Leste prevalensi skabies $17,3 \%$. 
Scabies adalah infeksi kulit yang disebabkan oleh Sarcoptes scabiei tungau (mite) berukuran kecil yang hidup di dalam kulit penderita. Menurut World Health Organization scabies merupakan salah satu daftar penyakit tropis terabaikan pada tahun 2013 dan diperkirakan mempengaruhi lebih dari 130 juta orang di seluruh dunia setiap saat. Menurut Internasional Alliance for the Control of Scabies (IACS) kejadian scabies bervariasi dari 0,3\% menjadi 46\%. Pada tahun 2010, diperkirakan bahwa efek langsung dari scabies menyebabkan lebih dari 1,5 miliar orang setiap tahun hidup dengan cacat, dan efek tidak langsung dari komplikasi pada fungsi ginjal dan kardiovaskular yang jauh lebih besar.

Sarcoptes scabiei termasuk filum Arthopoda, kelas Arachnida, ordo Ackarnia, superfamili Sarcoptes. Pada manusia disebut Sarcoptes scabiei var. hominis. Secara morfologik agen adalah tungau kecil, berbentuk oval, punggungnya cembung dan bagian perutnya rata. Siklus hidup tungau ini yaitu setelah kopulasi (perkawinan) yang terjadi di atas kulit, jantan akan mati, sedangkan tungau betina yang telah dibuahi menggali terowongan dalam stratum korneum dan sambil meletakan telurnya. Proses perkembangbiakan begitu seterusnya terjadi di dalam kulit sehingga menyebabkan infeksi pada kulit.

Ciri khas dari scabies adalah gatal-gatal hebat, yang biasanya semakin memburuk pada malam hari. Lubang tungau tampak seperti garis bergelombang dengan panjang sampai 2,5 cm, kadang pada ujungnya terdapat beruntusan kecil. Lubang atau terowongan tungau dan gatal-gatal paling sering ditemukan dan dirasakan di sela-sela jari tangan, pada pergelangan tangan, sikut, ketiak, di sekitar puting payudara wanita, alat kelamin pria (penis dan kantong zakar), dan di sepanjang garis ikat pinggang serta bokong bagian bawah. Lama-lama terowongan ini sulit untuk dilihat karena tertutup oleh peradangan yang terjadi akibat penggaman

Penyakit skabies pada umumnya menyerang individu yang hidup berkelompok seperti di asrama, pesantren, lembaga pemasyarakatan, rumah sakit, perkampungan padat dan rumah jompo. Berdasarkan Departemen Kesehatan RI, prevalensi skabies di Indonesia sebesar 4,60 - 12,95 $\%$ dan skabies menduduki urutan ketiga dari 12 penyakit kulit tersering, sedangkan untuk negara yang sedang berkembang prevalensi skabies sekitar 6 - $27 \%$ dari populasi umum (Kementerian Kesehatan Republik Indonesia. 2012). Tujuan dari program pengabdian masyarakat ini adalah Untuk memberikan edukasi yang tepat kepada penghuni Rutan Perempuan Kelas II B Wirogunan tentang penyakit scabies. Serta memberikan edukasi kepada penghuni Rutan Perempuan Kelas II B Wirogunan tentang Sanitasi lingkungan dan Higiene perseorangan sebagai faktor penghambat terjadinya penularan scabies. Alasan diambilnya lokasi pengabdian masyarakat di Rutan Perempuan Kelas II B Wirogunan ini adalah, dari hasil survei sebelumnya didapatkan kasus scabies sebanyak 15 orang yang menderita scabies.

\section{METODE}

Metode yang digunakan dalam Program ini adalah Pendidikan Masyarakat yang terbagi menjadi tiga tahap, yaitu Persiapan, Pelaksanaan Program dan Evaluasi.

\section{Persiapan}

Pada tahap ini yang dilakukan terlebih dahulu adalah menyiapkan bahan dan alat. bahan dan Alat yang digunakan antara lain: Naskah dalam bentuk Power point untuk penyuluhan

LCD Projector, Laptop, Handphone untuk komunikasi. 


\section{Pelaksanaan program}

Program dilaksanakan di bulan Januari 2020 di Lembaga Pemasyarakatan Perempuan Kelas II B Yogyakarta terletak di Jalan Tamansiswa No. 6B Yogyakarta 55166. Sebelum acara dibagikan kuesioner yang berisi pertanyaan seputar pengetahuan tentang scabies.

\section{Evaluasi}

Setelah acara penyuluhan selesai dilaksanakan, program dievaluasi dengan cara membagikan kuesioner yang berisi pertanyaan seputar pengetahuan tentang scabies, sehingga dapat dinilai peningkatan pengetahuan sebelum penyuluhan dan sesudah penyuluhan.

\section{HASIL DAN PEMBAHASAN}

1. Tahap Persiapan

Pada tanggal 16 Januari 2020 dilakukan persiapan antara lain melakukan checkcross ke pihak Rutan Kelas II B Yogyakarta untuk memastikan bisa tidaknya acara berlangsung. Tanggal 17 Januari 2020 mengambil surat perizinan dari Kantor Kemenkumham untuk diserahkan ke Rutan Kelas II B Yogyakarta sebagai syarat berlangsungnya acara.

2. Tahap Pelaksanaan Program

Pada tanggal 18 Januari 2020 dilaksanakan acara penyuluhan tentang Scabies di Rutan Kelas II B Yogyakarta tepatnya di ruang aula Rutan Kelas II B Yogyakarta sebanyak kurang lebih 100 peserta dari penghuni Lapas, dengan narasumber saya sendiri (Ubaidillah) dari Stikes Surya Global Yogyakarta.

Para peserta sangat antusias menyimak informasi yang saya berikan, dimana beberapa peserta ada yang mengajukan pertanyaan berkaitan dengan scabies. Pertanyaan yang diajukan antara lain:

a. Bagaimana cara penularan penyakit Scabies (Gudikan)?

b. Apakah pinjam baju teman bisa menyebabkan tertularnya Scabies?

c. Apakah penyakit scabies ini dapat diobati?

Satu persatu pertanyaan dari peserta penyuluhan saya jawab. Penularan penyakit scabies yang paling utama adalah lewat kontak langsung seperti berjabat tangan dengan penderita scabies, tidur bersama dengan penderita scabies, berpelukan hingga hubungan seksual. Penularan selanjutnya adalah lewat kontak tidak langsung seperti bertukar handuk atau baju, serta penggunaan alat tidur bersama.

Penyakit Scabies merupakan penyakit kulit yang dapat diobati dengan obat-obatan seperti permethrin, lindane, sulfur, atau crotamiton. Biasanya obat-obatan ini tersedia di apotik dalam bentuk cream atau ointment. 


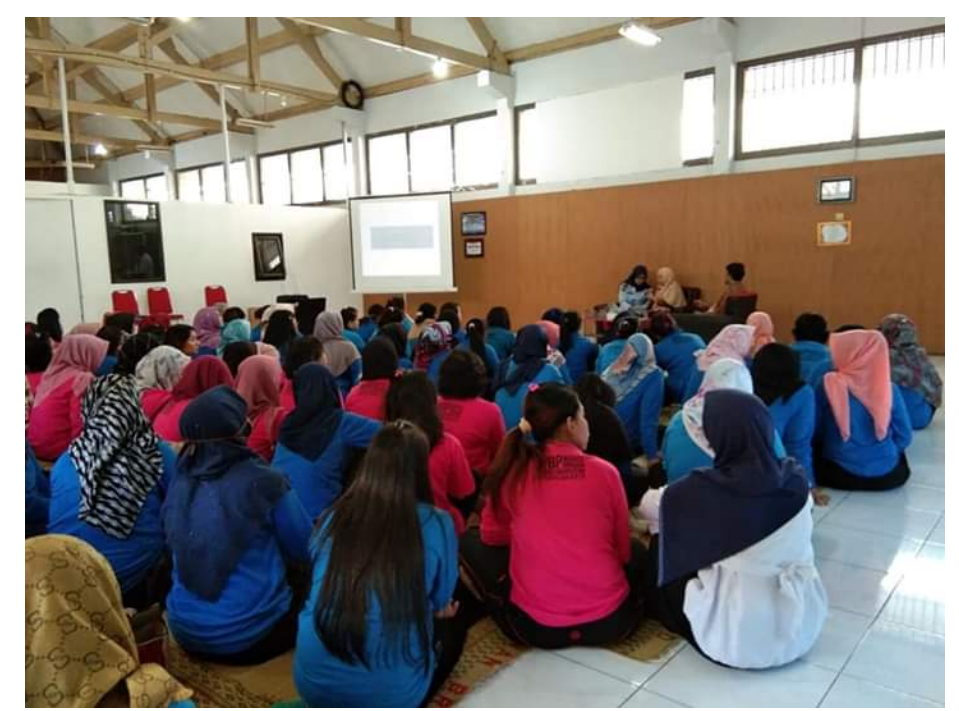

Gambar 1. penyuluhan tentang penyakit Scabies

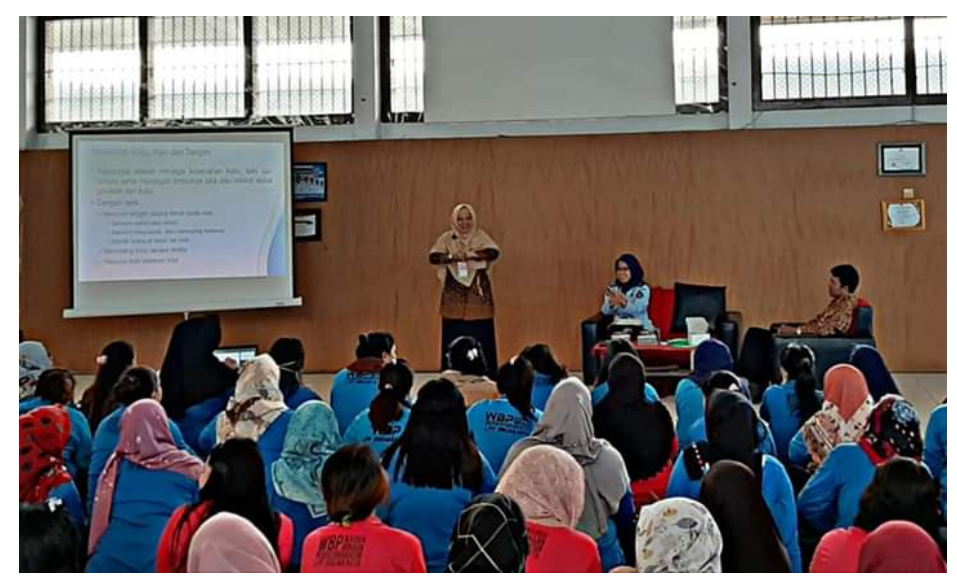

Gambar 2. Tanya jawab tentang penyakit scabies

\section{Tahap Evaluasi}

Kegiatan yang ketiga yaitu evaluasi pelaksanaan acara. Evaluasi yang pertama yaitu sebelum acara penyuluhan, dengan membagikan kuesioner yang berisi pertanyaan seputar pengetahuan tentang scabies. tepat saat acara selesai dengan mengajukan beberapa pertanyaan kepada para peserta. Antara lain menanyakan apakah berjabat tangan dapat menularkan scabies? Dijawab dapat menularkan scabies secara serempak. Pertanyaan lainnya berkaitan dengan higiene dan sanitasi perseorangan seperti, penggunaan baju dan handuk bersama-sama, menjemur kasur, bantal dan guling secara rutin. Kemudian membagikan lagi lembar kuesioner yang sama kepada peserta. Dari hasil pengisian kuesioner diperoleh peningkatan pengetahuan tentang scabies dan higiene dan sanitasi perseorangan.

\section{KESIMPULAN}

Kesimpulan dari acara pengabdian masyarakat ini adalah dengan pendidikan dan penyuluhan tentang penyakit scabies di Lapas, terdapat peningkatan pengetahuan tentang scabies dan higiene dan sanitasi perseorangan. pengetahuan Penyakit Scabies merupakan penyakit kulit 
yang disebabkan oleh Tungau sarcoptes scabiei yang bisa diminimalkan penularannya dengan Sanitasi lingkungan dan Higiene perseorangan. Saran yang harus diperhatikan adalah perlu peningkatan kesadaran masyarakat akan Sanitasi lingkungan dan Higiene perseorangan yang lebih baik sehingga penyakit-penyakit akibat kurangnya Sanitasi lingkungan dan Higiene perseorangan, dapat ditekan penularannya.

\section{UCAPAN TERIMA KASIH}

Dengan selesainya acara pengabdian masyarakat ini, penulis ingin mengucapkan terima kasih kepada

1. Kepala Rutan Perempuan Kelas II B Wirogunan Yogyakarta,

2. Kepala kantor Kementerian Hukum dan Hak Asasi Manusia Yogyakarta,

3. Stikes surya Global Yogyakarta yang banyak membantu terlaksananya acara tersebut.

\section{DAFTAR PUSTAKA}

Currie, B. J. (2015). ". Scabies and Global Control of Neglected Tropical Diseases." The New England Journal of Medicine.

MC Carthy, J. S., D .J . Kemp, S .P. Walton and B .J . Currie (2004). "Scabies : More than just an irritation ". Postgrad. Med. J, National Library Of Medicine: 5.

Nugraheni, A., Pratama NP, A dan Wibowo. D. A. (2016). "Hubungan Tingkat Pengetahuan Santri dengan Prilaku Pencegahan Skabies di Pondok Pesantren Darut Taqwa Bulusan Semarang." Jurnal Kedokteran Diponegoro. Volume 05.

O'Donnel, B. F., S. O'Loughlin and F .C. Powell (1990). "Management of crusted scabies." hit . J . Dermatol 8.

Partosoedjono, S. (2013). Scabies dan kualitas sanitasi masyarakat.

Soedarto (2009). Penyakit Menular di Indonesia. Jakarta, Sagung Seto.

WHO (2013). "Epidemiology and Management of Common Skin Disease in Children in Developing Countries." WHO/FCH/CAH/05.12.

Widiasih, D. A. d. B., S. (2012). Epidemiologi Zoonosis di Indonesia. Yogyakarta, Gajah Mada University Press.

Zulkoni, A. (2011). Parasitologi. Yogyakarta, Nuha Medikai. 